\title{
Optimization of Biodiesel Transesterification using ANN and Fuzzy Logic
}

\author{
Susarla Venkata Ananta Rama Sastry, B. Sarva Rao, G. Ravi Kishor
}

\begin{abstract}
The high energy demand in domestic sector coupled with pollution brought by extensive exploitation of conventional fuels in an industrialized world makes it mandatory to boost renewable energy sources having lesser environmental impact than non-renewable ones. In this regard bio-diesel can be considered as a more reliable resource of energy that can be used readily in the existing engines. Biodiesel is formed by transesterification reaction of alcohol and triglycerides under a catalyst. In this paper, Bio-diesel is produced from karanja (pongamia pinnata) oil in sono reactor at varied methanol-oil ratios and varied catalyst ratios. Yield was found at different molar ratios of methanol:oil (6:1; 4.5:1; 3:1), different $\mathrm{KOH}$ concentrations (2.0 wt \%; 1.5 wt \%; 1.0 wt \%) and different times (15 min; $30 \mathrm{~min}$; $45 \mathrm{~min}$; $60 \mathrm{~min}$ ). The biodiesel thus obtained conformed to ASTM D6751 standards. The optimum conditions of maximum yield are determined at $50^{\circ} \mathrm{C}$ temperature, $45 \mathrm{~min}$ reaction time, 4.5:1 methanol:oil ratio and 1.5\% of $\mathrm{KOH}$. The results obtained are well in accord with the literature. Also ultrasonic vibration used for production of biodiesel proves to be promising technique. The biodiesel thus produced is analyzed using various tests to obtain its properties. Further optimization techniques namely Artificial Neural Network and Fuzzy Logic have been applied for modeling the reaction and finding the optimum yield at different conditions. The yield predicted by using ANN and Fuzzy logic was compared with the experimental yield. The ANN and Fuzzy can precisely calculate as per the experimental data with $R^{2}=0.998$ and $R^{2}=0.995$, respectively.
\end{abstract}

Index Terms: ANN; Biodiesel; Fuzzy logic; Karanja; Transesterification.

\section{INTRODUCTION}

A. Transesterification Reaction for Producing Biodiesel With the growing energy demands and increased dependence on the conventional sources and increased fear for their depletion brought up the urge for a better alternative which would actually replace the existing conventional fuels, that is petrol and diesel. Our society and economy are greatly dependent on the fuels. Biodiesel is the product obtained from the trans-esterification of the oils in presence of catalyst and alcohol which produces monoalkylesters along with glycerol. The monoalkylesters is called as biodiesel.

Revised Manuscript Received on December 30, 2019.

* Correspondence Author

Dr. S.V.A.R.Sastry*, Associate Professor, Chemical Engineering Department, MVGR College of Engineering (A), Vizianagaram, A.P., India. E-mail: svarsastry@yahoo.com

Dr. B. Sarva Rao, Associate Professor, Chemical Engineering Department, MVGR College of Engineering (A), Vizianagaram, A.P., India.

Mr. G. Ravi Kishor, Assistant Professor, Chemical Engineering Department, MVGR College of Engineering (A), Vizianagaram, A.P., India.

(C) The Authors. Published by Blue Eyes Intelligence Engineering and Sciences Publication (BEIESP). This is an open access article under the CC BY-NC-ND license (http://creativecommons.org/licenses/by-nc-nd/4.0/)
Biodiesel thus obtained can be used directly as B100 or as blends (B20 which is the $20 \%$ of the biodiesel and $80 \%$ of the diesel). Using edible oils for making biodiesel is not realistic due to huge gap in supply and demand of those oils in different countries across the world. Under these conditions, non-edible oils have to be used to produce biodiesel. These are obtained in substantial amount and can also be developed significantly on semi-arid and waste lands in different parts of the world. Non-edible crops such as jojoba, karanja, mahua, and jatropa have $30 \%$ - $35 \%$ or more oil content in their nuts fruits or seeds [1] - [5]. Transesterification, also known as alcoholysis is the dislocation of alcohol from the ester by using alternative alcohol in a method which is analogous to hydrolysis, excepting for that in transesterification, there is alcohol in place of water. This process is extensively used to decrease the high viscosity of the triglycerides. Biodiesel can directly be used in the engines with no or slight modification of the engine. This is the most important feature of the fuel which makes it more important compared to other renewable sources where they cannot be actually be used in the existing techniques.The transesterification reaction is shown below [6] - [10].

Oil + 3 MeOH Catalyst 3 Biodiesel + Glycerol

\section{B. Optimization Techniques}

These are specific methods which can be used to determine efficient solution to any problem or design for any process. This is a major quantitative tool used in the industry for decision making. A wide variety of problems related to design, analysis, construction and operation of chemical plants can be resolved by using optimization techniques [11] - [15]. The process of transesterification produces biodiesel using oil and alcohol in presence of catalyst. The optimization techniques have been applied for operating parameters like alcohol-oil ratio, catalyst concentration and time for predicting the yield of biodiesel.

\section{Artificial Neural Network}

Artificial Neural Network (ANN) is a nonlinear mapping structure, based on the role of human brain. It is a function approximator which transforms inputs into outputs to best of its ability. It is a potent tool used for the modeling, particularly while basic data correlation is unidentified. ANN identifies and learns connected patterns among input data sets and analogous objective values. Once trained, it is used to calculate effect of fresh independent input data. ANN has enormous capability in analytical modeling which means that all characters relating unidentified condition can be offered to trained ANN, and the prediction of system is assured.

ANN also possesses the ability to generalize, predicting new outcomes from past trends [8], [13]. 


\section{Developing an ANN Model}

ANN is assembled with stratums of elements, and therefore is termed as multilayer ANN (Fig. 1). A stratum of units consists of units, which accomplish analogous tasks. The first stratum of multilayer ANN contains input units called as independent variables in statistical nomenclature. The last stratum of multilayer ANN contains output units called as dependent or response variables in statistical literature. All additional units in ANN model consist of hidden layers and are called as hidden units. Two functions govern the behavior of unit in a specific stratum, which usually are similar for all units in entire ANN [8], [13]

- the input function, and

- the output/activation function.

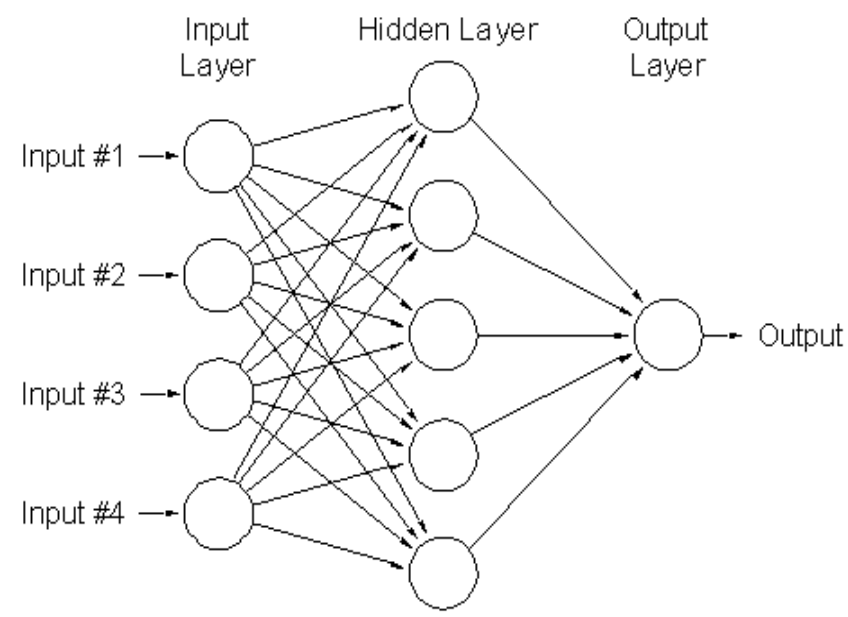

Fig. 1. ANN model

\section{Fuzzy Logic}

This is a type of probabilistic logic dealing with a logic which is fairly accurate rather instead of being exact or fixed. Fuzzy logic variables can also have a truth value which lies between 0 and 1, compared to the traditional binary sets (where the variables can take false or true values). Fuzzy logic can also be stretched to tackle the notion of fractional truth, where truth value can diverge amid entirely true and completely false. Fuzzy set theory shows enormous potential for efficient solving of the improbability in a problem [13].

\section{EXPERIMENTATION}

\section{A. Materials}

\section{- Karanja oil}

The feed material used for the production of biodiesel is Karanja oil. Karanja plants can be grown in semi-arid lands of the South Asian peninsula [14], [15]. For the present study, karanja oil has been obtained from the Adilabad district in Andhra Pradesh state of India [16] - [18].

Fatty acid structure of Karanja oil is as follows: Palmitic acid: 30.6 \% ; Stearic acid: $10.5 \%$; Oleic acid: $53.6 \%$; Linoleic acid: $1.5 \%$; Eicosanoic acid: 2.2 \%; Docosanoic acid: 1.6 $\%$.

\section{- Methanol}

Methanol is favored above other alcohols because of less cost and lower boiling point [16].

\section{- Potassium Hydroxide}

To increase transesterification reaction, alkali catalyst is utmost used because it influences the end more rapidly than the acid catalyst [17]. $\mathrm{KOH}$ is the general catalyst used during alkaline transesterification [18] - [20]. In addition to that soap development is furthermore fewer with $\mathrm{KOH}$ in contrast to $\mathrm{NaOH}$ [21], [22].

\section{B. Experimental Set-up}

The experimental setup (Fig. 2) contains sonochemical reactor, RB flask, and reflux condenser alongwith distillation equipment for the reclamation of methanol. Furthermore, filter paper, thermometer, funnel, beakers, conical flasks, SG bottle are needed for the experiments.

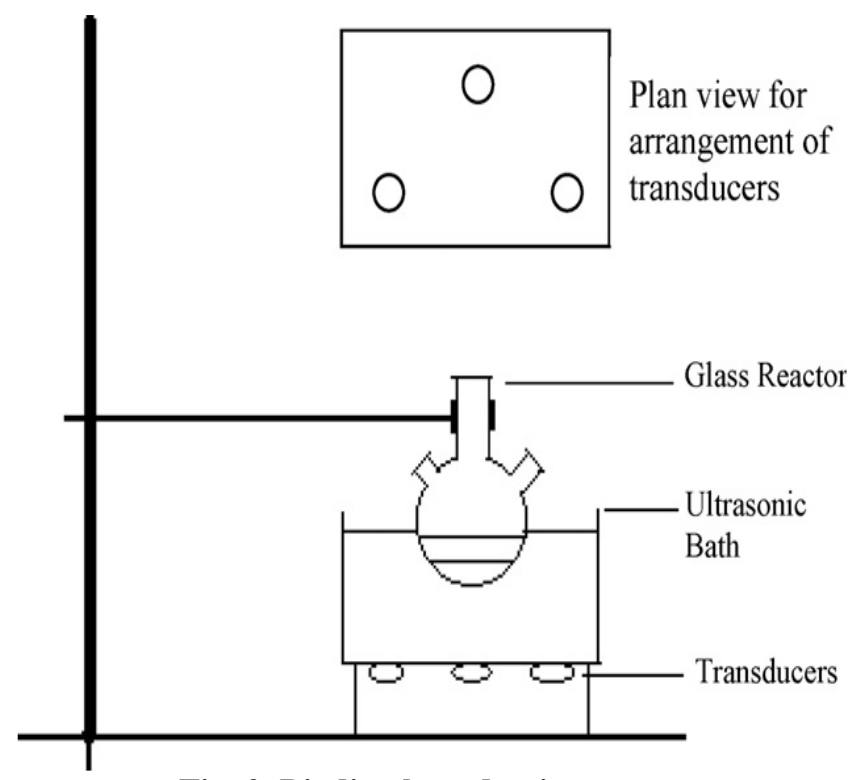

Fig. 2. Biodiesel production set-up

\section{Experimental Procedure}

$\mathrm{KOH}$ is dissolved in methanol, which is further mixed with karanja oil by vigorous stirring. The reaction mixture is dynamically excited up to a temperature of $50 \mathrm{deg}$. Celsius, for diverse time periods (15 minutes to 60 minutes). Once the reaction is over, mixture is slowly cooled. The product acquired is a consistent mixture of biodiesel along with glycerol. The product mixture is separated using separating funnel to remove glycerol. Biodiesel is collected and the yield is calculated. The process is reiterated for diverse reaction times, catalyst percentages and alcohol-oil ratios. An assessment of significant properties of the Karanja oil and the biodiesel from Karanja oil is provided in Table I.

- Yield = wt of biodiesel obtained after reaction / wt. of oil used for reaction.

Table-I: Comparison of the properties of Karanja oil and biodiesel from Karanja oil

\begin{tabular}{|l|l|l|}
\hline Property & KO-BD & KO \\
\hline Density (at $30^{\mathbf{}} \mathbf{C}$ ), kg/m & 830 & 880 \\
\hline${\text { Viscosity (at } \mathbf{4 0}^{\mathbf{0}} \mathbf{C} \text { ), stokes }}^{\circ}$ & 0.038 & 0.306 \\
\hline Flash Point, $^{\mathbf{0}} \mathbf{C}$ & 140 & 212 \\
\hline Fire Point, ${ }^{\mathbf{O}} \mathbf{C}$ & 148 & 222 \\
\hline Pour Point, $^{\mathbf{}} \mathbf{C}$ & -6 & -3 \\
\hline
\end{tabular}




\begin{tabular}{|l|l|l|}
\hline Cloud point, $^{\mathbf{}} \mathbf{C}$ & -3 & 3 \\
\hline Cetane Number & 49 & 38 \\
\hline Iodine Number, g/100g & 48 & 98 \\
\hline Acid value, $\mathbf{~ m g ~ K O H / g ~}$ & 0.25 & 6 \\
\hline
\end{tabular}

\section{Operating Parameters}

Experiments were performed at different temperatures (40 $60{ }^{\circ} \mathrm{C}$ ). The yield was found to be maximum at $50^{\circ} \mathrm{C}$ which is taken as the optimum temperature. The experiments were performed at the following operating parameters: Pressure in reactor (1atm), Methanol-oil molar ratio (6:1, 4.5:1, 3:1), Catalyst concentration ( $2 \%, 1.5 \%, 1 \% \mathrm{wt})$, Reaction time (15 min; 30 min; 45 min; 60 min).

\section{ANN MODEL BUILDING}

A multilayer feed-forward neural network educated by back propagation algorithm is centered on controlled procedure, i.e., the network builds a model grounded on cases of data with identified output [23] - [28]. (Fig. 3)

For training the ANN, which is a MLP Feed forward network with 2 hidden layers, we have used the following datasets obtained from 35 experiments. The hidden layers can be increased to improve accuracy. The numbers of epochs are taken as 50 , to increase the accuracy further.

$X=[1: 6: 15 ; 1: 4.5: 15 ; 1: 3: 15 ; 1.5: 6: 15 ; 1.5: 4.5: 15 ; 1.5: 3: 15 ;$ $2: 6: 15 ; 2: 4.5: 15 ; 2: 3: 15 ; 1: 6: 30 ; 1: 4.5: 30 ; 1: 3: 30 ; 1.5: 6: 30$; $1.5: 4.5: 30 ; 1.5: 3: 30 ; \quad 2: 6: 30 ; 2: 4.5: 30 ; 2: 3: 30 ; 1: 6: 45$; $1: 4.5: 45 ; 1: 3: 45 ; 1.5: 6: 45 ; 1.5: 4.5: 45 ; 1.5: 3: 45 ; 2: 6: 45$; $2: 4.5: 45 ; \quad 2: 3: 45 ; \quad 1: 6: 60 ; 1: 4.5: 60 ; 1: 3: 60 ; 1.5: 6: 60$; $1.5: 4.5: 60 ; 1.5: 3: 60 ; 2: 6: 60 ; 2: 4.5: 60]$

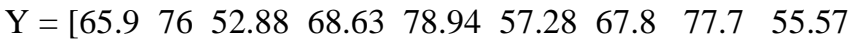
$\begin{array}{lllllllll}70.01 & 80.75 & 56.18 & 72.9 & 83.87 & 60.87 & 72.05 & 82.56 & 59.04\end{array}$ $\begin{array}{lllllllll}82.37 & 95 & 66.10 & 85.79 & 98.67 & 71.61 & 84.76 & 97.13 & 69.46\end{array}$ $\begin{array}{lllllllll}80.4 & 95 & 67.3 & 83.5 & 98.66 & 72 & 81.7 & 96.8 & \text { ] }\end{array}$

- Here X denotes set of input values. Therefore each set contains 3 values which denote Catalyst concentration (\%), Ratio (MeOH:Oil) and Time (hours) respectively. (corresponding to Optimal Temperature)

- And Y denotes set of output values or the yield of biodiesel (gms) corresponding to the given input values.
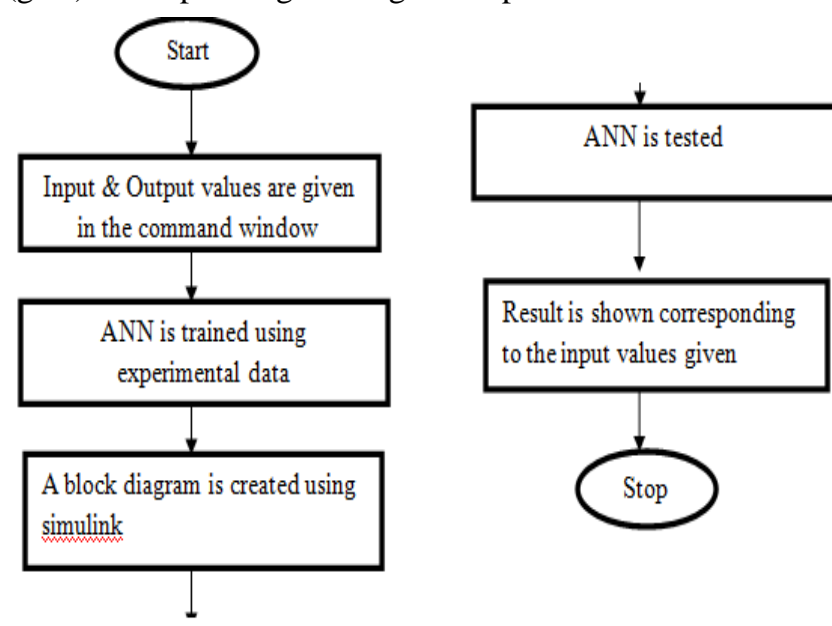

Fig. 3. ANN Flow sheet

\section{A. Training of the model}

The ANN has been trained with the following 35 experimental data sets.

Average error $=0.6 \% ; \mathrm{R}^{2}=0.998$

Where, $\mathrm{C}=$ catalyst concentration (wt \%)

$$
\begin{aligned}
& \mathrm{R}=\mathrm{MeOH} \text { :Oil ratio } \\
& \mathrm{T}=\text { time (hours) }
\end{aligned}
$$

\section{B. Validation of the trained model}

The trained ANN model has been validated with the input data set $\mathrm{C}, \mathrm{R}, \mathrm{T}$ as $2,3,60$ and output dataset as 70.8 . The ANN model gave the output as 70.85. The dataset for validation has been deliberately chosen to be well outside the experimental range for training so that it can accommodate datasets for various ranges of experimentation. The ANN yield has been compared with the experimental yield and the error is reported (Fig. 4, Fig. 5).

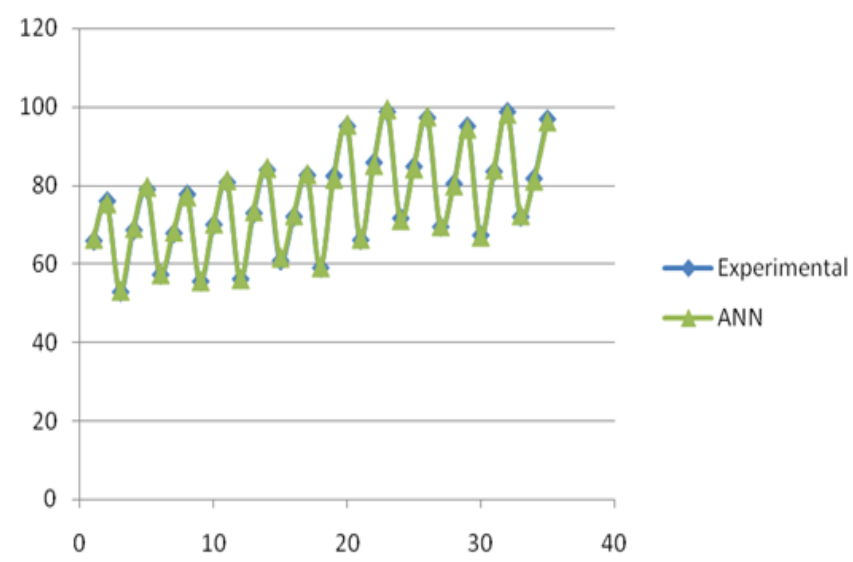

Fig. 4. Comparison of the biodiesel yield obtained for experiment and ANN

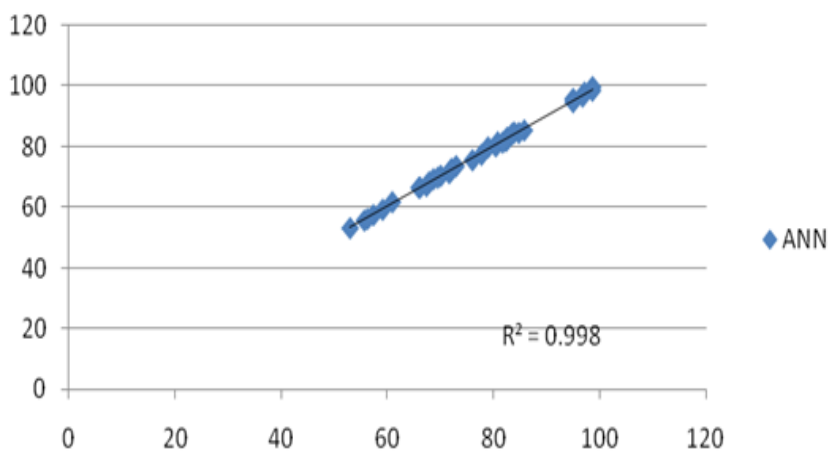

Fig. 5. Error of predicted yield by ANN w.r.t. to the experimental yield

\section{FUZZY LOGIC}

\section{A. Fuzzification}

By using the experimental data, each variable is ranged between their limits and represented by the membership functions (Table II). We have therefore selected triangular membership function and designed the variables. 
Table - II: Membership functions \& their range

\begin{tabular}{|c|c|c|c|c|c|c|}
\hline $\mathbf{s}$ & Variable & \multicolumn{5}{|c|}{ Member ship functions \& their range } \\
\hline $\mathbf{1}$ & $\begin{array}{c}\text { Catakyst } \\
\text { (wt) }\end{array}$ & $\begin{array}{l}\text { Low } \\
(0.5- \\
1.0)\end{array}$ & $\begin{array}{c}\text { Mediu } \\
\mathrm{m} \\
(1.0- \\
1.5)\end{array}$ & $\begin{array}{c}\text { High } \\
(1.5-2.0)\end{array}$ & -- & - \\
\hline 2 & $\begin{array}{c}\text { Ratio } \\
\text { (moles) }\end{array}$ & $\begin{array}{c}\text { Low } \\
(1.5-3)\end{array}$ & $\begin{array}{c}\text { Mediu } \\
\mathrm{m} \\
(3-4.5)\end{array}$ & $\begin{array}{l}\text { High } \\
(4.5-6)\end{array}$ & - & - \\
\hline 3 & $\begin{array}{l}\text { Time } \\
(\min )\end{array}$ & $\begin{array}{l}\text { Primary } \\
(0-15)\end{array}$ & $\begin{array}{c}\text { Second } \\
\text { ary } \\
(15-30)\end{array}$ & $\begin{array}{l}\text { Tertiary } \\
(30-45)\end{array}$ & $\begin{array}{l}\text { Quater } \\
\text { nary } \\
(45- \\
60)\end{array}$ & $\ldots$ \\
\hline 4 & $\begin{array}{c}\text { Biodiesel } \\
\text { (gms) }\end{array}$ & $\begin{array}{l}\text { Lowest } \\
(52-62)\end{array}$ & $\begin{array}{c}\text { Below } \\
\text { averag } \\
\mathrm{e} \\
(61-71)\end{array}$ & $\begin{array}{l}\text { Average } \\
(70-80)\end{array}$ & $\begin{array}{c}\text { Above } \\
\text { averag } \\
\text { e } \\
(80- \\
90)\end{array}$ & $\begin{array}{c}\text { Highe } \\
\text { st } \\
(89- \\
99)\end{array}$ \\
\hline
\end{tabular}

\section{B. Rule Base}

Rule base includes developing rules forming the basis of the experimental values. There are 35 experimental values for which 35 rules are created taking the basis of membership functions and their ranges (Table III). There are 9 input membership function (3 for each variable) and 3 output membership functions. So rules were made using 'and' operator as follows. Using the rules, a fuzzy model was prepared in simulink as shown below. The program is run for different input values similar to that in ANN.

\begin{tabular}{|c|c|c|c|c|}
\hline $\mathrm{N}_{\mathrm{C}, \mathrm{R}}^{\mathbf{T}}$ & $\underset{\text { Primary }}{\text { Table-1 }}$ & $\begin{array}{l}\text { I: Fuzzy R } \\
\text { Secondary }\end{array}$ & $\begin{array}{r}\text { lle Base } \\
\text { Tertiary }\end{array}$ & Quaternary \\
\hline Low, Low & Lowvest & $\begin{array}{l}\text { Below } \\
\text { average }\end{array}$ & $\begin{array}{l}\text { Belowv } \\
\text { average }\end{array}$ & $\begin{array}{l}\text { Belowv } \\
\text { average }\end{array}$ \\
\hline $\begin{array}{l}\text { Medium, } \\
\text { Low }\end{array}$ & $\begin{array}{l}\text { Below } \\
\text { average }\end{array}$ & $\begin{array}{l}\text { Below } \\
\text { average }\end{array}$ & $\begin{array}{l}\text { Below } \\
\text { average }\end{array}$ & $\begin{array}{l}\text { Below } \\
\text { average }\end{array}$ \\
\hline High, Low & Lowest & $\begin{array}{l}\text { Below } \\
\text { average }\end{array}$ & $\begin{array}{l}\text { Belowv } \\
\text { average }\end{array}$ & $\begin{array}{l}\text { Below } \\
\text { average }\end{array}$ \\
\hline $\begin{array}{c}\text { Low, } \\
\text { Medium }\end{array}$ & Average & $\begin{array}{l}\text { Above } \\
\text { average }\end{array}$ & $\begin{array}{l}\text { Above } \\
\text { average }\end{array}$ & $\begin{array}{l}\text { Above } \\
\text { average }\end{array}$ \\
\hline $\begin{array}{l}\text { Medium, } \\
\text { Medium }\end{array}$ & Average & $\begin{array}{l}\text { Above } \\
\text { average }\end{array}$ & Highest & Highest \\
\hline $\begin{array}{c}\text { High, } \\
\text { Medium }\end{array}$ & Average & $\begin{array}{l}\text { Above } \\
\text { average }\end{array}$ & Highest & Highest \\
\hline Low, High & $\begin{array}{l}\text { Below } \\
\text { average }\end{array}$ & $\begin{array}{l}\text { Below } \\
\text { average }\end{array}$ & $\begin{array}{l}\text { Above } \\
\text { average }\end{array}$ & $\begin{array}{l}\text { Above } \\
\text { average }\end{array}$ \\
\hline $\begin{array}{c}\text { Medium, } \\
\text { High }\end{array}$ & $\begin{array}{l}\text { Below } \\
\text { average }\end{array}$ & $\begin{array}{l}\text { Below } \\
\text { average }\end{array}$ & $\begin{array}{l}\text { Above } \\
\text { average }\end{array}$ & $\begin{array}{l}\text { Above } \\
\text { average }\end{array}$ \\
\hline High, High & $\begin{array}{l}\text { Belowv } \\
\text { average }\end{array}$ & $\begin{array}{l}\text { Below } \\
\text { average }\end{array}$ & $\begin{array}{l}\text { Above } \\
\text { average }\end{array}$ & $\begin{array}{l}\text { Above } \\
\text { average }\end{array}$ \\
\hline
\end{tabular}

C. Inference
Inference refers to predicting the output corresponding to an unknown input from a known relationship between input and output variables created previously as fuzzy rule base.

\section{Defuzzification}

Defuzzification is the process of producing a quantifiable result from aggregate fuzzy output obtained from inferred values of fuzzy outputs corresponding to given fuzzy rules, and aggregating them. Here we have used Centre of Gravity method for defuzzification.

\section{E. Validation of the model}

The Fuzzy has been trained with the following 35 experimental data sets.

Average error $=1.37 \% ; \mathrm{R}^{2}=0.995$

Where, $\mathrm{C}=$ catalyst concentration (\%)

$$
\begin{aligned}
& \mathrm{R}=\mathrm{MeOH} \text { :Oil ratio } \\
& \mathrm{T}=\text { time(hours) }
\end{aligned}
$$

Fuzzy result $=$ weight of biodiesel(gms)

Both experimental values and Fuzzy result indicate weight of biodiesel obtained in different experiments. The Fuzzy yield has been compared with the experimental yield and the error is reported (Fig. 6, Fig. 7).

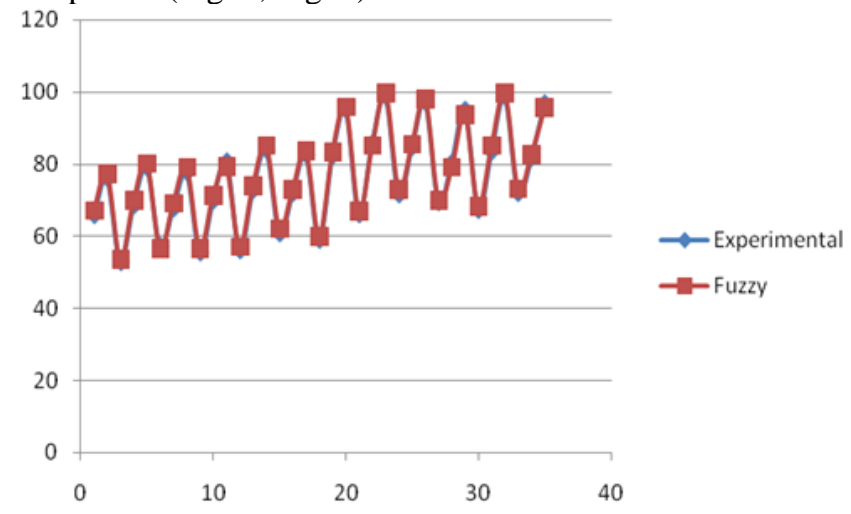

Fig. 6. Comparison of the biodiesel yield obtained for experiment and Fuzzy

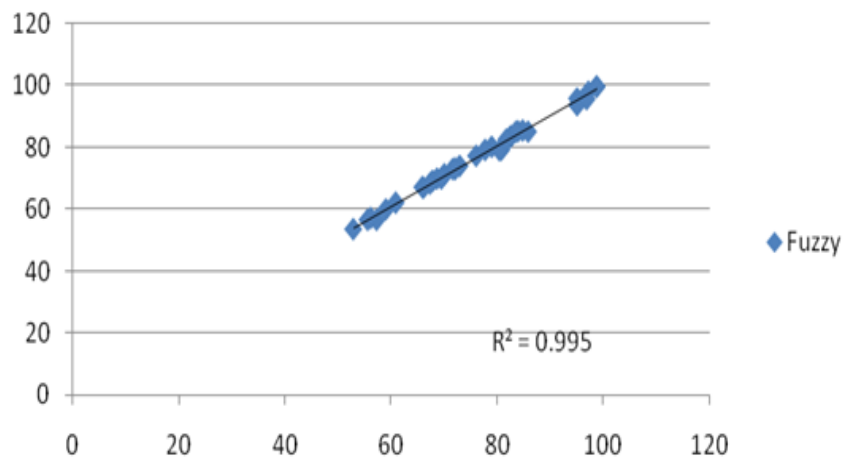

Fig. 7. Error of predicted yield by Fuzzy w.r.t. to the experimental yield

\section{RESULTS \& DISCUSSIONS}

The overall comparison of ANN and Fuzzy yield with the experimental yield has been shown in Fig. 8 and Table IV. The average error for Fuzzy logic and ANN are $1.37 \%$ and $0.6 \%$ respectively. ANN $\left(\mathrm{R}^{2}=0.998\right)$ was somewhat superior than Fuzzy $\left(\mathrm{R}^{2}=0.995\right)$ in data fit and assessment abilities. 
For the optimum experimental condition of C:R:T at [1.5:4.5:45] the experimental yield was highest at $98.67 \%$. The yield predicted by ANN and Fuzzy are $99.4 \%$ and 99.6 $\%$ respectively, which are in good concurrence with the experimental yield within the range of experimental errors. These results can also be extended to other alcohols (and bases of different strength) and temperature ranges (or other reaction conditions).

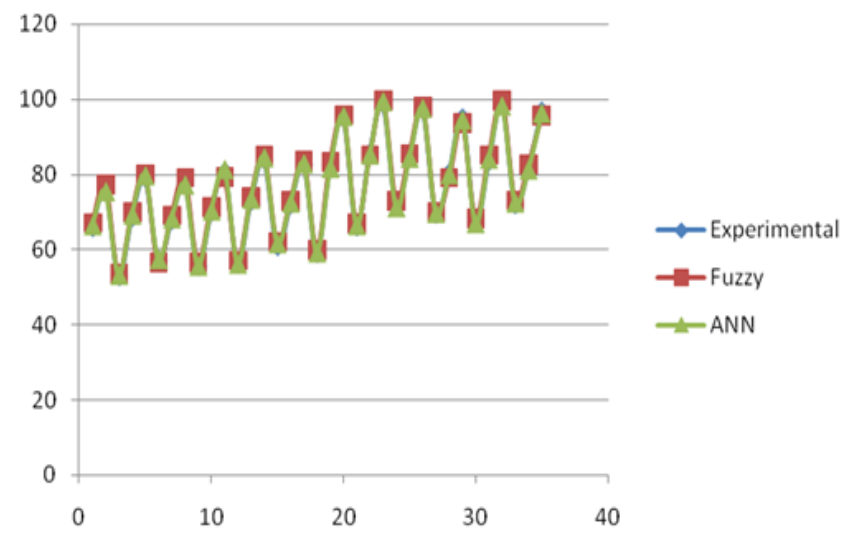

Fig. 8. Overall plot of the biodiesel yield obtained for Experiment, Fuzzy and ANN

Table-IV: Overall Results for Fuzzy logic and ANN

\begin{tabular}{|l|l|l|l|}
\hline S.No & Parameter & Fuzzy logic & ANN \\
\hline 1 & Average Error & $1.37 \%$ & $0.6 \%$ \\
\hline 2 & $\mathrm{R}^{2} \%$ & 0.995 & 0.998 \\
\hline 3 & $\begin{array}{l}\text { Yield at C:R:T of } \\
{[1.5: 4.5: 45]}\end{array}$ & $99.6 \%$ & $99.4 \%$ \\
\hline
\end{tabular}

\section{CONCLUSION}

The produced biodiesel conformed to ASTM D6751 standards. The ANN and Fuzzy can precisely calculate the experimental data with $\mathrm{R}^{2}=0.998$ and $\mathrm{R}^{2}=0.995$, respectively. ANN was found to give more accurate prediction. Hence ANN can be used for predicting the optimized yields in transesterification reaction.

\section{REFERENCES}

1. Vivek and A.K Gupta, Biodiesel Production from Karanja Oil, J of Sci \& Ind Res, 63, 39 (2004).

2. Sastry, S.V.A.R., Biodiesel Production: Lab Studies to Pilot Plant Studies. M. Tech Thesis, Department of Chemical Engineering, Indian Institute of Technology, Delhi (2005).

3. W Zhou, S.K. Konar, D.G.B. Boocock, Ethyl esters from the single-phase base-catalyzed ethanolysis of vegetable oils, JAOCS, $\mathbf{8 0}$, 367 (2003).

4. Y.C Sharma, B.Singh, Development of biodiesel from karanja, a tree found in rural India, Fuel, 86, 1740 (2007).

5. S.K Karmee, A. Chadha Preparation of biodiesel from crude oil of Pongamia pinnata, Bioresour Technol, 96, 1425 (2005).

6. H Han, W Cao, J Zhang. Preparation of biodiesel from soybean oil using supercritical methanol and CO2 as co-solvent, Process Biochem, 40, 3148 (2005).

7. Y Watanabe, Y Shimada, A Sugihara, H Noda, H Fukuda, Y Tominga, Continuous production of biodiesel fuel from vegetable oil using immobilized Candida antarctica lipase, J Am Oil Chem Soc, 77, 355 (2000).

8. H. Lu, Y Liu, H Zhou., Y Yang., M Chen., B Liang. Production of biodiesel from Jatropha curcas L. oil, Computers and Chemical Engineering, 33, 1091 (2009).

9. B Freedman, E.H. Pryde, T.L. Mounts, Variables affecting the yields of fatty esters from transesterified vegetable oils, JAOCS, 61, 1638 (1984).

10. K Gerhard, The Biodiesel Handbook, AOCS Press, ISBN 978-1893997-79-0 (2005).

11. K G Georgogianni, M G Kontominas, P J Pomonis, D Avlonitis, V Gergis, Conventional and in situ transesterification of sunflower seed oil for the production of biodiesel, Fuel Process Technol, 89, 503 (2008).

12. R Peña, R Romero, S Martínez, M Ramos, A Martínez, R Natividad, Transesterification of castor oil: effect of catalyst and co-solvent, Ind Eng Chem Res, 48, 1186 (2009).

13. S.V.A.R.Sastry, Ch.V.R. Murthy, Fuzzy logic Application in Process Modeling of Biodiesel Reactor, Sp. Iss. of Intl. J of Comp. Applications, 66, 34 (2013).

14. J Qian, F Wang, S Liu, Z Yun, In situ alkaline transesterification of cottonseed oil for production of biodiesel and nontoxic cottonseed meal, Bioresour Technol, 99, 9009 (2008).

15. Suresh Kumar, A K Gupta \& S N Naik, Conversion of non-edible oil into bio-diesel, J of Sci \& Ind Res, 62, 124 (2003).

16. A S Ramadhas, S Jayaraj, C Muraleedharan, Biodiesel production from high FFA rubber seed oil, Fuel, 84, 335 (2005).

17. F Ma, M A Hanna, Biodiesel production: a review, Bioresour Technol, 70, 1 (1999).

18. H Fukuda, A Kondo, H Noda, Biodiesel fuel production by transesterification of oils, J Biosci Bioeng, 92, 405 (2001).

19. S.V.A.R.Sastry, Ch.V.R. Murthy, Synthesis of biodiesel by insitu transesterification of karanja oil, BJSIR, 49, 211 (2014).

20. LT Thanh, K Okitsu, Y Sadanaga, N Takenaka, Y Maeda, H Bandow, Ultrasound assisted production of biodiesel fuel from vegetable oils in a small scale circulation process, Bioresour Technol, 101, 639 (2009).

21. A T Kiakalaieha, N A Saidina Amin, A Zarei, I Noshadi, Transesterification of waste cooking oil by heteropoly acid (HPA) catalyst: Optimization and kinetic model, Applied Energy, 102, 283 (2013).

22. M Rajendra, PC Jena, $H$ Raheman, Prediction of optimized pretreatment process parameters for biodiesel production using ANN and GA, Fuel, 88, 868 (2009).

23. V Novák, I Perfilieva, J Močkoř, Mathematical principles of fuzzy logic, Dodrecht: Kluwer Academic, ISBN 0-7923-8595-0 (1999).

24. Ahlawat, Nishant, Ashu Gautam, Nidhi Sharma, Use of Logic Gates to Make Edge Avoider Robot, International Journal of Information \& Computation Technology, 6, 630 (2014).

25. AK Gupta, SVAR Sastry, Developing the rate equation for Biodiesel Production Reaction, Department of Chemical Engineering, Indian Institute of Technology Delhi (2006).

26. KS Ravi Kumar, SVAR Sastry, Application of PI, fuzzy logic and ANN in improvement of power quality using UPQC. IET Digital Library, 316 (2011).

27. G.K.Jha, Manual on Artificial Neural Networks, Indian Agricultura Research Institute, New Delhi, India, http://www.iasri.res.in (2012).

28. Amin Talebian-Kiakalaieh, Nor Aishah Saidina Amin, Alireza Zarei, Iman Noshadi, Transesterification of waste cooking oil by heteropoly acid (HPA) catalyst: Optimization and kinetic model, Applied Energy, 102, 283 (2013)

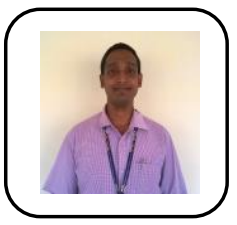

\section{AUTHORS PROFILE}

Dr. S. V. A. R. Sastry has 15 years of teaching and research experience in the area of chemical engineering in providing engineering education to under-graduate and graduate students. He did B.Tech from NIT Jalandhar, M.Tech from IIT Delhi and Ph.D from JNTU Kakinada, all in Chemical Engineering with a special focus on Renewable Energy. He has guided graduate students in their projects in the area of Fluidization \& Heat Transfer. He has authored 20 international books in the area of Renewable Energy, Unit Operations \& Heat Transfer. He has published more than $\mathbf{3 0}$ research papers in the area of renewable energy in reputed International journals and presented papers in more than 30 International Conferences.

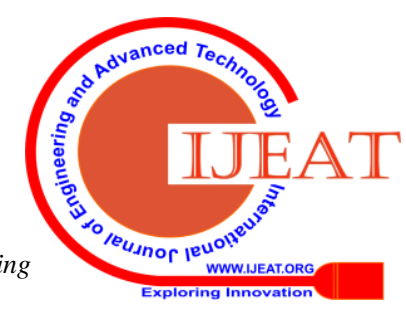


He is a Member Scientist of CORE GROUP of Scientists on Tree Borne Oil seeds for promotion, utilization and socio-economic linkages in Southern India. He is a Senior Professional Member of Institution of Engineers, Indian Institute of Chemical Engineers, International Association of Computer Science and Information Technology and Institute for Engineering Research and Publication. He is a Reviewer for International journals and Permanent reviewer for three Elsevier Journals (Energy Conversion \& Management; Journal of Cleaner Production; AIChE). He has been awarded Outstanding reviewer status by Elsevier, U.S. and granted full free access to Scopus by Elsevier, U.S. He is an Editor for two International Journals. He is an Editorial Board member for three International Journals. His Biography has been published in Marquis Who's Who in the World, 31st, 32nd \& 33rd editions consecutively. He got the University Best Teacher Award from JNTU Kakinada in 2013. He is a Recipient of International awards from IBC, Cambridge, England. He got selected for inclusion in "100 Best Educators of 2014", "2000 OUTSTANDING INTELLETUALS OF THE 21ST CENTURY", "CAMBRIDGE CERTIFICATE for Outstanding Educational Achievement", and the prestigious "Leading Professionals of the world-2014" (published as online directory) by International Biographical Centre (IBC), Cambridge, England.

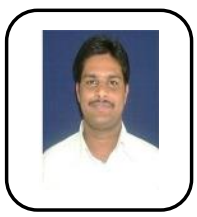

Dr. B. Sarva Rao did B.Tech (Chemical Engineering), M.Tech \& PhD from JNTU Hyderabad. He has 16 years of academic and research experience. He has published 12 papers in International Journals; 20 papers in International Conferences and 2 International Books. He is a Life Member of IIChE, IE(I) and ISTE.

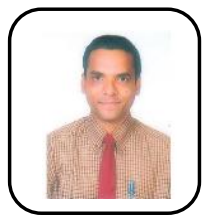

Mr. G. Ravi Kishor did B.Tech (Chemical Engineering) from Andhra University, M.Tech from IIT Bombay and Masters from Georgia Institute of Technology, Atlanta, U.S with Chemical Engineering specialization. He has about 14 years of diverse experience in both industry and academics. $\mathrm{He}$ is a Member of AIChE and IEEE. 